\title{
Evaluate the efficacy of Antimicrobial activity of aqueous extract of Nigella Sativa seeds powder on Staphylococcus Aureus
}

\author{
Nishanthini K*, Paheerathan V, Piratheepkumar R and Chanjuka U \\ Unit of Siddha Medicine, Trincomalee Campus, Eastern University, Sri Lanka
}

\begin{abstract}
Siddha system of medicine is the main traditional medicine which is very popular in south India and north and east Sri Lanka. In this system herbal, mineral and metal are mainly use for the medicine preparation and to treat the diseases. Each and every part of the herbs can be used for various, multiple ailments because of their different phyto constituents. In Siddha medicine system has been classified into Aga marunthu (Internal) and Pura marunthu (External) having 32 forms of medicines in each. The external remedies are very useful for topical ulcers, skin diseases like eczema, psoriasis bacterial and fungal infections. The purpose this study was Evaluate the efficacy of Antibacterial activity of aqueous extract of Nigella sativa seeds powder against Staphylococcus aureus by used disk diffusion method. The result has been evaluated as the diameter of the zone of inhibition of microbial growth showed that the different concentration $(100 \%, 50 \%, 25 \%)$ of Nigella sativa seed powder's aqueous extract more effective against Staphylococcus aureus. Mean value of the hot extract $100 \%, 50 \%, 25 \%$ respectively $12.19 \pm 1.91 \mathrm{~mm}, 7.63 \pm 2.32 \mathrm{~mm}$ and $3.78 \pm 1.73 \mathrm{~mm}$ and the mean value of Cold extract were $9.45 \pm 1.32 \mathrm{~mm}, 4.21 \pm 0.92 \mathrm{~mm}$ and $2.71 \pm .64 \mathrm{~mm}$. Standard maintained $18 \mathrm{~mm}$ of zone of inhibition. Among, the hot and cold extract, $100 \%$ of hot extract was showed more significant affect against Staphylococcus aureus which was $12.19 \mathrm{~mm}$. Finally, this study was concluded that the Nigella seeds powder can be used as an antibacterial agent.
\end{abstract}

KEYWORDS: Nigella sativa; Hot and cold aqueous extract; Different concentration; Disk diffusion method; Staphylococcus aureus

\section{INTRODUCTION}

Herbal plants are being an effective source of both traditional and modern medicines. They are genuinely useful for primary healthcare. The medicinal plants produce wide range array of bioactive molecules and rich source of medicines. Nigella sativa belongs to the family Ranuculacea. It is $35-50 \mathrm{~cm}$ tall and commonly known as black cumin. The seeds have traditionally been used for thousands of years in Middle East, Far East and Asian as a food additive and as an herbal health aid. Also, its uses extended for carminative, diuretic, lactogogue and vermifuge, fever, common cold, Headache, asthma, rheumatic disease, warts, strings of scorpion, bite of snake [1]. The black cumin seeds and its oil extract act as antimicrobial, anthelmintic, immune stimulant, antihypertensive, anti-inflammatory, anti-cancer, antioxidant, hypoglycemic, spasmolytic and bronchodilator [2]. One of the central themes of success in human therapeutics in the $20^{\text {th }}$ century was the discovery and development of antimicrobial and antibiotic agents for the treatment of micro-organism infections. A huge array of antimicrobial agent has been introduced and antibiotics can use effectively to treat major infectious disease. According to the publication of WHO in 2017, Staphylococcus aureus is one of the anti-biotic resistant microorganisms and considered to be a multi drug organism as well.

\section{MATERIAL AND METHODS}

The working bench was sterilized and decontaminated using $70 \%$ ethanol from $95 \%$ ethanol. Before every research work proceedings glassware were wrapped with foil clear papers and autoclaved for 15 minutes at $1200^{\circ} \mathrm{C}$.

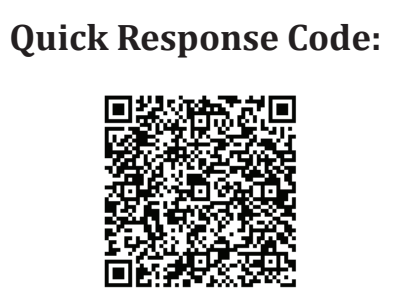

Address for correspondence: Nishanthini K, Unit of Siddha Medicine, Trincomalee Campus, Eastern University, Sri Lanka

Received: April 19, $2021 \quad$ Published: May 13, 2021

How to cite this article: Nishanthini K, Paheerathan V, Piratheepkumar R and Chanjuka U. Evaluate the efficacy of Antimicrobial activity of aqueous extract of Nigella sativa seeds powder on Staphylococcus aureus. 2021- 3(3) OAJBS.ID.000279. DOI: 10.38125/OAJBS.000279 


\section{Preparation of Plant Extract}

Nigella sativa seeds were collected from local shop at Trincomalee district and taxonomically authenticated. After that it was washed thoroughly with tap water and dried in sun shed. Then powdered by using grinder. Finally stored in airtight glass container and labelled.

Cold water extraction: Ten (10) mg of powder was added to $10 \mathrm{ml}$ of distilled water and crushed well by using motor and pestle. Then it was centrifuged for 10 minutes in 10000rpm. The supernatant was separated carefully and stored at room temperature [3].

Hot water extraction: Ten (10) mg of powder was added to $10 \mathrm{ml}$ of distilled water and crushed well by motor and pestle. Then it was placed in water bath $\left(1000{ }^{\circ} \mathrm{C}\right)$ for 5 minutes. After allowing it to cool, it was centrifuged for 10 minutes in $10000 \mathrm{rpm}$. The supernatant was separated carefully and stored at room temperature.

Different concentration was prepared in order to identify the optimum concentration in Hot and cold extracts $(25 \mathrm{mg} / 10 \mathrm{ml}, 50$ $\mathrm{mg} / 10 \mathrm{ml}$, and $100 \mathrm{mg} / 10 \mathrm{ml}$ ).

\section{Preparation of Mǔeller-Hinton Agar}

Mŭeller-Hinton agar were prepared from a commercially available dehydrated base according to the manufacturer's instructions, immediately after autoclaving, allowed it to cool down in a $45-500{ }^{\circ} \mathrm{C}$ water bath. Poured the freshly prepared and cooled medium into glass flat bottomed petri dished on a level, horizontal surface to give a uniform depth of approximately $4 \mathrm{~mm}$. This was corresponding to 60 to $70 \mathrm{ml}$ of medium for plates with diameters of $150 \mathrm{~mm}$ and $25-30 \mathrm{ml}$ for plates with a diameter of $100 \mathrm{~mm}$.The agar medium allowed to at room temperature and, unless the plates were stored in a refrigerator $\left(2\right.$ to $\left.80^{\circ} \mathrm{C}\right)$.

\section{Selection and Source of Micro-Organism}

To assess the antimicrobial activity of the extracts, two bacterial cultures were obtained from Batticoloa Teaching Hospital, Batticaloa. The bacterial strain was of a gram-positive
Staphylococcus aureus. The culture was subcultured on MŭellerHinton agar and was left to incubate at $37{ }^{\circ} \mathrm{C}$ for 24 hours. The subcultures were then stored at $5^{\circ} \mathrm{C}$, until further use.

\section{Preparation of Inoculum}

During the disk diffusion assay, bacteria from the subculture were dissolved in saline solution under aspetic conditions. This was compared against the 0.5 MacFarland standard to obtain a bacterial concentration between 1-2 x 108 colony forming units per milliliter $(\mathrm{CFU} / \mathrm{ml})$ and was streaked against petri dishes contained with Mǔ́eller-Hinton agar, under sterile condition. Thereafter, filter paper disk was placed. Amoxicillin was used as positive control and distilled water was used as negative control.

\section{Preparation of Positive Control}

Amoxicillin was prepared from 500mg tablets suspended in distilled water to a final stock concentration of $10 \mathrm{mg} / \mathrm{ml}$ and filter sterilized.

\section{Statistical Analysis}

Inhibition zone were measured by using Vernier caliper. All available data were entered into a database using the SPSS statistical software (SPSS for windows, version 21.0, IBM Corporation, NY, USA) and were analyzed using one-way analysis of variance (ANOVA) to compare the mean inhibitory zones and Independent Sample $\mathrm{T}$ test. The values were considered to be statistically different at $\mathrm{p}<0.05$ mean $+/$ - standard deviation.

\section{RESULTS}

\section{Disk Diffusion Assay}

The antibacterial activity of the aqueous extract (Hot/Cold) of N.sativa were investigated against Staphylococcus aureus. The results indicated that both extracts displayed antibacterial activity against bacterial strains at concentrations of $10 \mathrm{mg} / 10 \mathrm{ml}$, $5 \mathrm{mg} / 10 \mathrm{ml}$ and $2.5 \mathrm{mg} / 10 \mathrm{ml}$. Table 1 displayed the mean inhibitory zones for the bacterial strains, ranging from $(2.71 \pm 0.64 \mathrm{~mm})$ to $(12.19 \pm 1.91 \mathrm{~mm})$. The maximum inhibitory zone was exhibited by the positive control $(18.33 \pm 2.08)$. There were no inhibition zones recorded for the negative control.

Table 1: Zones of inhibition for N.sativa hot and cold seed extracts against Staphylococcus aureus.

\begin{tabular}{|c|c|c|}
\hline & \multicolumn{2}{|c|}{ Staphylococcus Aureus } \\
\hline & \multicolumn{2}{|c|}{ Mean Inhibitory Zones (mm) } \\
\hline Concentration $(\mathrm{mg} / \mathrm{ml})$ & N.sativa Hot Extract & N.sativa Cold Extract \\
\hline $10 \mathrm{mg} / 10 \mathrm{ml}$ & $12.19 \pm 1.91 \mathrm{~mm}$ & $9.45 \pm 1.32 \mathrm{~mm}$ \\
\hline $5 \mathrm{mg} / 10 \mathrm{ml}$ & $7.63 \pm 2.32 \mathrm{~mm}$ & $4.21 \pm 0.92 \mathrm{~mm}$ \\
\hline $2.5 \mathrm{mg} / 10 \mathrm{ml}$ & $3.78 \pm 0.1 .73 \mathrm{~mm}$ & $2.71 \pm 0.64 \mathrm{~mm}$ \\
\hline
\end{tabular}

Data expressed as mean \pm SD

The extracts displayed zones of inhibition in a dose-dependent manner, with an exception for the hot extract tested against Staphylococcus aureus. Results from the hot aqueous extract tested against Staphylococcus aureus, exhibited the maximum zone of inhibition for $10 \mathrm{mg} / 10 \mathrm{ml}(12.19 \pm 1.91 \mathrm{~mm}$ followed by $5 \mathrm{mg} / 10 \mathrm{ml}$ $(7.63 \pm 2.32 \mathrm{~mm})$ and $2.5 \mathrm{mg} / 10 \mathrm{ml}(3.78 \pm 0.1 .73 \mathrm{~mm})$ than compared to the cold extract $10 \mathrm{mg} / 10 \mathrm{ml}(9.45 \pm 1.32 \mathrm{~mm})$ followed by $5 \mathrm{mg} / 10 \mathrm{ml} \quad(4.21 \pm 0.92 \mathrm{~mm})$ and $2.5 \mathrm{mg} / 10 \mathrm{ml} \quad(2.71 \pm 0.64 \mathrm{~mm})$ (Table 2).

Results from the one-way ANOVA statistical analysis, indicating that there was no statically significant difference $(p<0.05)$ between the N.sativa hot extract inhibitory zones and each concentration against Staphylococcus aureus (Table 3).

Results from the one-way ANOVA statistical analysis, indicating that there was no statistically significant difference $(p<0.05)$ between the N.sativa hot extract inhibitory zones and each concentration against Staphylococcus aureus.

The data presented in Table 1-3. indicated that the Nigella sativa seed hot extract exhibited the highest zone of 
inhibition at $10 \mathrm{mg} / 10 \mathrm{ml}(12.19 \pm 1.91 \mathrm{~mm})$ for Staphylococcus aureus which subsequently reduced with the decrease in concentration of the extract, $5 \mathrm{mg} / 10 \mathrm{ml}(7.63 \pm 2.32 \mathrm{~mm})$ and $2.5 \mathrm{mg} / 10 \mathrm{ml}(3.78 \pm 0.1 .73 \mathrm{~mm})$. The comparison of means was displayed a statistically significant difference $(p=0.03, p<0.05)$ at each concentration of Nigella sativa seed hot extract against Staphylococcus aureus, among Nigella sativa seeds cold extract the highest zone of inhibition was also exhibited at $10 \mathrm{mg} / 10 \mathrm{ml}$ $(9.45 \pm 1.32 \mathrm{~mm})$ followed by $5 \mathrm{mg} / 10 \mathrm{ml}(4.21 \pm 0.92 \mathrm{~mm})$ and $2.5 \mathrm{mg} / 10 \mathrm{ml}(2.71 \pm 0.64 \mathrm{~mm})$. The mean inhibitory zones for the hot extract displayed a statistically significant difference $(p=0.00$, $p<0.05$ ) with each concentration. There was no significant difference between the Nigella sativa hot and cold extract at a concentration of $10 \mathrm{mg} / 10 \mathrm{ml}$ against Staphylococcus aureus (Table 4).

Table 2: p-value of cold extract of Nigella sativa among different concentration.

\begin{tabular}{|c|c|c|c|c|c|}
\hline \multicolumn{7}{|c|}{ ANOVA } & F & Sig. \\
\hline & Sum of Squares & Df & Mean Square & 103.896 & 0.33 \\
\hline Between Groups & 1014.181 & 4 & 253.545 & & \\
\hline Within Groups & 48.808 & 20 & 2.44 & & \\
\hline Total & 1062.989 & 24 & & \\
\hline
\end{tabular}

Table 3: p-value of hot extract of Nigella sativa among different concentration.

\begin{tabular}{|c|c|c|c|c|c|}
\hline \multicolumn{7}{|c|}{ ANOVA } & F & Sig. \\
\hline & Sum of Squares & Df & Mean Square & 420.67 & 0 \\
\hline Between Groups & 1070.387 & 4 & 267.597 & & \\
\hline Within Groups & 12.722 & 20 & 0.636 & & \\
\hline Total & 1083.11 & 24 & & \\
\hline
\end{tabular}

Table 4: Independent t- test Analysis of $25 \%$ of Hot and cold extract.

\begin{tabular}{|c|c|c|c|c|}
\hline Extract & N & Mean & SD & Std. Error Mean \\
\hline Inhibition Hot & 5 & 3.788 & 1.73024 & 0.77379 \\
\hline Inhibition Cold & 5 & 2.776 & 0.64562 & 0.28873 \\
\hline
\end{tabular}

\begin{tabular}{|c|c|c|c|c|c|c|c|c|c|}
\hline & Levene's Test for & \multicolumn{8}{|c|}{$t$-Test for Equality for Mean } \\
\hline & \multirow[t]{2}{*}{$\mathbf{F}$} & \multirow[t]{2}{*}{ Sig. } & \multirow[t]{2}{*}{$\boldsymbol{t}$} & \multirow[t]{2}{*}{ df } & \multirow[t]{2}{*}{$\begin{array}{c}\text { Sig. } \\
\text { (2tailed) }\end{array}$} & \multirow[t]{2}{*}{$\begin{array}{c}\text { Mean } \\
\text { Differences }\end{array}$} & \multirow[t]{2}{*}{$\begin{array}{c}\text { Std. Error } \\
\text { Differences }\end{array}$} & \multicolumn{2}{|c|}{$\begin{array}{l}\text { 95\% Confidences } \\
\text { Interval of the } \\
\text { Differences }\end{array}$} \\
\hline & & & & & & & & Lower & Upper \\
\hline $\begin{array}{c}\text { Equal } \\
\text { variances } \\
\text { assumed }\end{array}$ & 4.544 & 0.66 & 1.255 & 8 & 0.255 & 1.012 & 0.8259 & -0.89253 & 2.91653 \\
\hline $\begin{array}{c}\text { Equal } \\
\text { variances } \\
\text { not assumed }\end{array}$ & & & 1.255 & 5.093 & 0.274 & 1.012 & 0.8259 & -1.09947 & 3.12347 \\
\hline
\end{tabular}

Results from the independent sample $t$ test for $25 \%$ of Hot and Cold aqueous extracts of N.sativa elicits that since the Significant (2-tailed) values $0.255,0.274$ are $>p=0.05$. Therefore, there is no significant difference between the mean variances of both hot and cold extracts. Also, from the analysis it could be concluded that 95\% confidence that the actual competency between mean variances of hot and cold extracts lies between (-0.89253 to 2.92) and (-1.09947 to 3.12). Also, the mean value of hot extract is much higher $3.78 \pm 1.73$ than that of the cold extract $2.77 \pm 0.64$ (Table 5).

Results from the independent sample $t$ test for $50 \%$ of Hot and Cold aqueous extracts of N.sativa elicits that since the Significant (2-tailed) values $0.016,0.026$ were $<p=0.05$. Therefore, there is significant difference between the mean variances of both hot and cold extracts. Also, from the analysis it could be concluded that $95 \%$ confidence that the actual competency between mean variances of hot and cold extracts lies between (0.84-6.00) and (0.59-6.25). Also, the mean value of hot extract was much higher $7.63 \pm 2.32$ than that of the cold extract $4.21 \pm 0.93$ (Table 6).
Results from the independent sample $t$ test for $100 \%$ of Hot and Cold aqueous extracts of N.sativa elicits that since the Significant (2-tailed) values $0.03,0.033$ were $<p=0.05$.

Therefore, there is a significant difference between the mean variances of both hot and cold extracts. Also, from the analysis it could be concluded that $95 \%$ confidence that the actual competency between mean variances of hot and cold extracts lies between (0.34-5.15) and (0.29-5.21).

Also, the mean value of hot extract was much higher $12.19 \pm 1.92$ than that of the cold extract $9.45 \pm 1.32$ (Figure 1).

Hence, according to the above histogram analysis standard value of inhibition for both extracts were between $18 \mathrm{~m}$. Compared with the cold extract hot extract was more efficient for inhibit the growth of staphylococcus aureus. Among the three different concentrations $(10 \mathrm{mg} / 10 \mathrm{ml}, 5 \mathrm{mg} / 10 \mathrm{ml}$ and $2.5 \mathrm{mg} / 10 \mathrm{ml}) 10 \mathrm{mg} / 10 \mathrm{ml}$ was elicited the highest mean rate of inhibition for both the extracts. 
Table 5: Independent $t$ - test Analysis of $50 \%$ of Hot and cold extract.

\begin{tabular}{|c|c|c|c|c|}
\hline Extract & N & Mean & SD & Std. Error Mean \\
\hline Inhibition Hot & 5 & 7.634 & 2.32143 & 1.03817 \\
\hline Inhibition Cold & 5 & 4.21 & 0.92906 & 0.41549 \\
\hline
\end{tabular}

\begin{tabular}{|c|c|c|c|c|c|c|c|c|c|}
\hline & $\begin{array}{l}\text { Levene's Test for } \\
\text { Equality of Variances }\end{array}$ & \multicolumn{8}{|c|}{$t$-Test for Equality for Mean } \\
\hline & \multirow[t]{2}{*}{$\mathbf{F}$} & \multirow[t]{2}{*}{ Sig. } & \multirow[t]{2}{*}{$\boldsymbol{t}$} & \multirow[t]{2}{*}{ df } & \multirow[t]{2}{*}{$\begin{array}{c}\text { Sig. } \\
\text { (2tailed) }\end{array}$} & \multirow[t]{2}{*}{$\begin{array}{c}\text { Mean } \\
\text { Differences }\end{array}$} & \multirow[t]{2}{*}{$\begin{array}{l}\text { Std. Error } \\
\text { Differences }\end{array}$} & \multicolumn{2}{|c|}{$\begin{array}{l}\text { 95\% Confidences } \\
\text { Interval of the } \\
\text { Differences }\end{array}$} \\
\hline & & & & & & & & Lower & Upper \\
\hline $\begin{array}{c}\text { Equal } \\
\text { variances } \\
\text { assumed }\end{array}$ & 0.649 & 0.444 & 2640 & 8 & 0.030 & 2.74800 & 1.041100 & 0.34746 & 5.14854 \\
\hline $\begin{array}{c}\text { Equal } \\
\text { variances } \\
\text { not assumed }\end{array}$ & & & 2640 & 7.110 & 0.033 & 2.74800 & 1.04100 & 0.29413 & 5.20187 \\
\hline
\end{tabular}

Table 6: Independent t- test Analysis of $100 \%$ of Hot and cold extract.

\begin{tabular}{|c|c|c|c|c|}
\hline Extract & N & Mean & SD & Std. Error Mean \\
\hline Inhibition Hot & 5 & 12.198 & 1.91514 & 0.85648 \\
\hline Inhibition Cold & 5 & 9.45 & 1.3231 & 0.59171 \\
\hline
\end{tabular}

\begin{tabular}{|c|c|c|c|c|c|c|c|c|c|}
\hline & $\begin{array}{l}\text { Levene's Test for } \\
\text { Equality of Variances }\end{array}$ & \multicolumn{8}{|c|}{$t$-Test for Equality for Mean } \\
\hline & \multirow[t]{2}{*}{$\mathbf{F}$} & \multirow[t]{2}{*}{ Sig. } & \multirow[t]{2}{*}{$\boldsymbol{t}$} & \multirow[t]{2}{*}{ df } & \multirow[t]{2}{*}{$\begin{array}{c}\text { Sig. } \\
\text { (2tailed) }\end{array}$} & \multirow[t]{2}{*}{$\begin{array}{c}\text { Mean } \\
\text { Differences }\end{array}$} & \multirow[t]{2}{*}{$\begin{array}{c}\text { Std. Error } \\
\text { Differences }\end{array}$} & \multicolumn{2}{|c|}{$\begin{array}{l}95 \% \text { Confidences } \\
\text { Interval of the } \\
\text { Differences }\end{array}$} \\
\hline & & & & & & & & Lower & Upper \\
\hline $\begin{array}{c}\text { Equal } \\
\text { variances } \\
\text { assumed }\end{array}$ & 8.016 & 0.022 & 3.062 & 8 & 0.016 & 3.42400 & 1.11823 & 0.34746 & 5.14854 \\
\hline $\begin{array}{c}\text { Equal } \\
\text { variances } \\
\text { not assumed }\end{array}$ & & 8 & 0.016 & 3.42400 & 0.026 & 3.42400 & 1.11823 & 0.59008 & 6.25792 \\
\hline
\end{tabular}

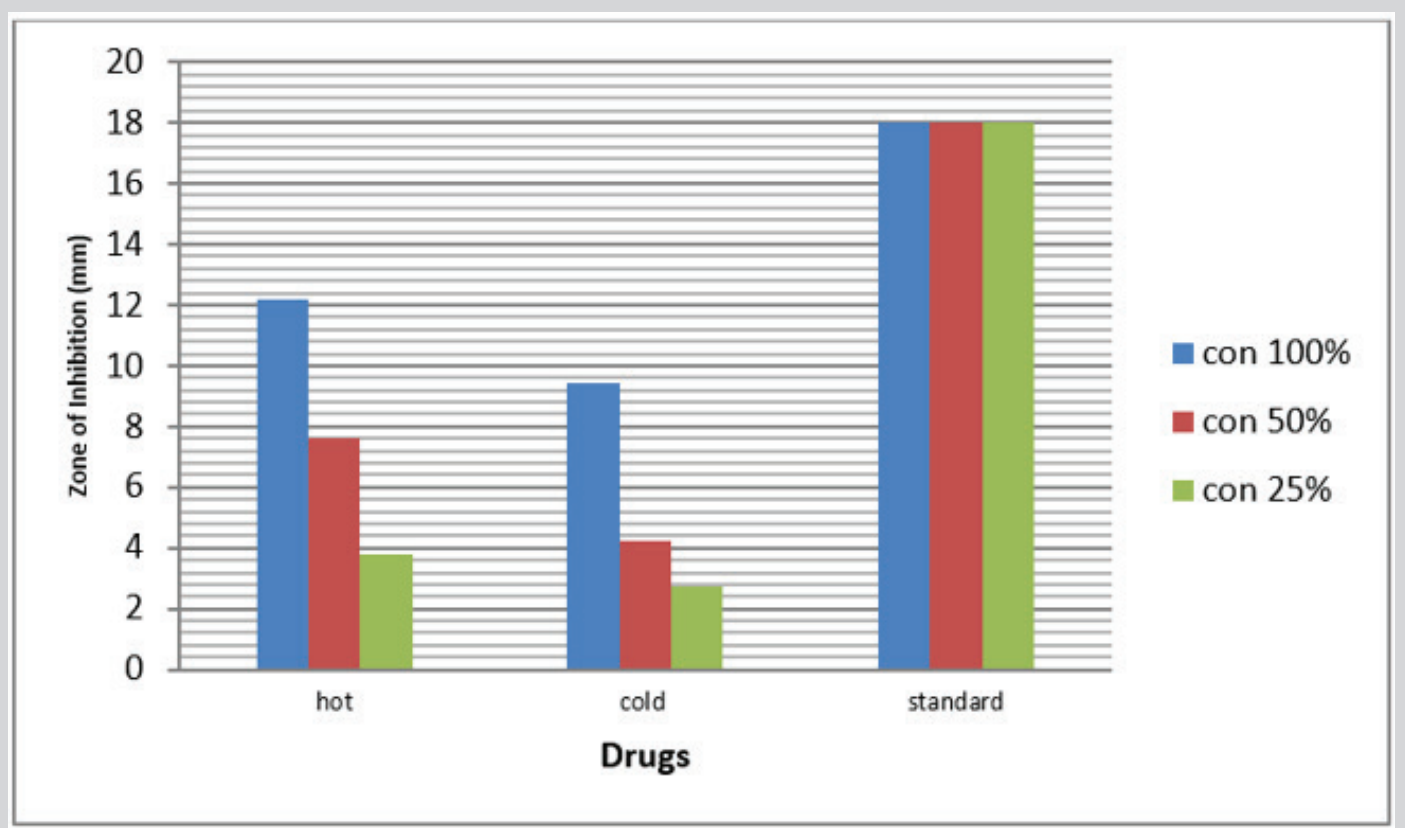

Figure 1: Effectiveness of Nigella sativa against Staphylococcus aureus in different concentration of hot and cold extract. 


\section{Discussion}

Nigella sativa is one of the special traditional herbal plants in siddha system of medicine which is very effective for all kinds of skin disorders and respiratory disorder. The antibacterial activities of Nigella sativa were tested against bacterial strain of Staphylococcus aureus in these studies. Antibacterial and antimicrobial activity of medicinal plant extract tested was more pronounced against Gram positive bacteria than Gram negative bacteria [4]. Many research findings elicits that Thymoquinone and Thymohydroquinone were the main chemical components present in N.Sativa responsible for the anti-bacterial activity. Further antibacterial activity of Nigella sativa stated on their studies by [5-10].

The antibacterial activity of Nigella sativa study against Staphylococcus aureus presented by elicit that aqueous plant extract of Nigella sativa showed significant antimicrobial and antifungal activity [11-13]. The antimicrobial activity of hot and cold queues extract of Nigella seeds powder has not been previously reported. As it already reported in previous studies, that Nigella sativa has an antimicrobial activity and this study suggest that hot extract of Nigella seeds powder show more significant effect than cold extract of Nigella sativa seeds powder. This study was investigated that antimicrobial effect of hot and cold aqueous extract of Nigella sativa on Staphylococcus aureus. The highest zone of inhibition against Staphylococcus aureus was $(12.19 \pm 1.9 \mathrm{~mm})$ was observed at $100 \%$ of hot aqueous extract of Nigella sativa $(10 \mathrm{mg} / 10 \mathrm{ml})$. $100 \%$ cold extract of Nigella sativa seed has moderate antibacterial effect on Staphylococcus aureus. In this study minimum inhibitory concentration was not carried out, however zone diameter of different concentration, hot and cold extract were reported here in (Table 2).

According to the test of homogeneity variance of hot and cold extracts of N.sativa the significant values were greater than that of the $p$ value 0.05 (Hot: $0.560>p=0.05$ ) (Cold: $0.690>p=0.05$ ). Therefore the results were considered to be insignificant hence one way ANOVA was used to analyze the maximum inhibition of N.sativa in both hot and cold extracts of different concentrations against the growth of Staphylococcus aureus. According, this result the standard was maintained in the range of $18 \mathrm{~mm}$, in the zone of inhibition of hot and cold extract was gradually decreased depend on the concentration and also Mohammade [14], was elicited that aqueous plant extract of Nigella sativa showed significant antimicrobial and antifungal activity.

The data presented in Table 1-3 indicated that the Nigella sativa seed hot extract was exhibited the highest zone of inhibition at $10 \mathrm{mg} / 10 \mathrm{ml}(12.19 \pm 1.91 \mathrm{~mm})$ for Staphylococcus aureus which subsequently reduced with the decrease in concentration of the extract, $5 \mathrm{mg} / 10 \mathrm{ml}(7.63 \pm 2.32 \mathrm{~mm})$ and $2.5 \mathrm{mg} / 10 \mathrm{ml}(3.78 \pm 0.1 .73 \mathrm{~mm})$. The comparison of means was displayed a statistically significant difference $(p=0.03, p<0.05)$ at each concentration of Nigella sativa seed hot extract against Staphylococcus aureus, among Nigella sativa seeds cold extract the highest zone of inhibition was also exhibited at $10 \mathrm{mg} / 10 \mathrm{ml}$ $(9.45 \pm 1.32 \mathrm{~mm})$ followed by $5 \mathrm{mg} / 10 \mathrm{ml}(4.21 \pm 0.92 \mathrm{~mm})$ and $2.5 \mathrm{mg} / 10 \mathrm{ml}(2.71 \pm 0.64 \mathrm{~mm})$. The mean inhibitory zones for the hot extract were displayed a statistically significant difference $(p=0.00, p<0.05)$ with each concentration. There was no significant difference between the Nigella sativa hot and cold extract at a concentration of $10 \mathrm{mg} / 10 \mathrm{ml}$ against Staphylococcus aureus [1419].
Antibacterial activity of two main compounds of black cumin seeds which are Thymoquinone and Thymohydroquinone was investigated their interaction with some common antibiotics were stated by Halawani on his report. Nigella sativa Essential oil with high concentration of carvanol and Thymole are more sensible against bacteria. Both Thymoquinone and Thymohydroquinone showed synergism when combined with all tested antibiotics against the Gram positive and Gram negative S.aureus resistance in highly susceptible to TQ. In my studies also were showed more significant against $100 \%$ of hot concentration of Nigella sativa. Mashhadan found that the aqueous extract was not show any effect, but other extracts (methanol, chloroform) showed high inhibitory effect against all the tested microorganisms including Staphylococcus aureus, this was stated by Hussine. But on my studies Hot and cold extract were showed significant effect with different concentration which showed more significant on $10 \mathrm{mg} / 10 \mathrm{ml}$ of hot extract of Nigella sativa [20-26].

Hanafy (1991) reported that different concentration showed that microgram concentrations ( 25400 \&disc) of the ether extract of Nigella sativa seeds inhibited growth of several species of pathogenic bacteria representing Gram positive- Staphylococcus aureus and Gram-Negative Escherichia coli. This gave more clues to my studies and $100 \%$ hot extract was showed more significant. Mohammad A [16] stated about that, Anaerobic bacteria are normal commensals and reside in human skin and mucous membranes, thus may cause endogenous infections, such as diarrhoea, aspiration pneumonia, lung abscess, brain abscess, and meningitis, TQ showed a significant antimicrobial activity against anaerobic bacteria although much weaker than metronidazole. So, this study helped me in the way of select the amoxicillin as standard $[27,28]$.

The extract displayed zones of inhibition in a dose-dependent manner, with an exception for the hot extract tested against Staphylococcus aureus. Results from the hot aqueous extract tested against Staphylococcus aureus, exhibited the maximum zone of inhibition for $10 \mathrm{mg} / 10 \mathrm{ml}(12.19 \pm 1.91 \mathrm{~mm}$ followed by $5 \mathrm{mg} / 10 \mathrm{ml}$ $(7.63 \pm 2.32 \mathrm{~mm})$ and $2.5 \mathrm{mg} / 10 \mathrm{ml}(3.78 \pm 0.1 .73 \mathrm{~mm})$ than compared to the cold extract $10 \mathrm{mg} / 10 \mathrm{ml}(9.45 \pm 1.32 \mathrm{~mm})$ followed by $5 \mathrm{mg} / 10 \mathrm{ml}(4.21 \pm 0.92 \mathrm{~mm})$ and $2.5 \mathrm{mg} / 10 \mathrm{ml}(2.71 \pm 0.64 \mathrm{~mm})[29$ 31].

\section{CONCLUSION}

Antibiotics that once readily cured a wide range of infections are becoming and developing antibiotic resistance. Scientist have realized an immense potential in natural products from medicinal plant to serve as an alternative source of combating infections in human beings which may be of lower cost and lower toxicity. This research finally concludes that aqueous extract of Nigella sativa seeds has significant antimicrobial activity against Staphylococcus aureus. Among that hot aqueous of Nigella sativa more significant against Staphylococcus aureus.

\section{REFERENCES}

1. Eman T (2009) Antimicrobial activity of thymoquinone and thymohydroquinone of nigella sativa l. and their interaction with some antibiotics. Advances in Biological Research.

2. Jayaweera D (2006) Medicinal plant used in ceylon, The National science foundation, Srilanka 235-243.

3. Khan UA, Rahman H, Niaz Z, Qasim M, Khan J, et al. (2013) Antibacterial activity of some medicinal plants against selected human pathogenic bacteria 3(4): 272-274. 
4. Bourgou S, Pichette A, Marzouk B, Legault J (2012) Antioxidant, antiinflammatory, anticancer and antibacterial activities of extracts from nigella sativa (black cumin) plant parts. Journal of Food Biochemistry 36(5): 539-546.

5. Halawani E (2009) Antibacterial activity of thymoquinone and thymohydroquinone of nigella sativa l. and their interaction with some antibiotics. Advances in Biological Research 3(56): 148-152.

6. Randhawa M, Alenazy A, Alrowaili M, Basha J (2017) An active principle of Nigella sativa L, thymoquinone, showed significant antimicrobial activity against anaerobic bacteria. J Intercult Ethnopharmacol 6(1): 97.

7. Salman MT, Khan RA, Shukla I (2008) Antimicrobial activity of nigella sativa linn. Seed oil against multi-drug resistant bacteria from clinical isolates. Ind J Nat Products Res 7(1): 10-14.

8. Emeka LB, Emeka PM, Tahir MK (2015) Antimicrobial activity of Nigella sativa L. seed oil against multi-drug resistant Staphylococcus aureus isolated from diabetic wounds. Pak J Pharm Sci 28(6): 1985-1990.

9. Rogozhin EA, Oshchepkova YI, Odintsova TI, Khadeeva NV, Veshkurova ON, et al. (2011) Novel antifungal defensins from Nigella sativa L. seeds. Plant Physiol Biochem 49(2): 131-137.

10. Botnick I, Xue W, Bar E, Ibdah M, Schwartz A, et al. (2012) Distribution of primary and specialized metabolites in Nigella sativa seeds, a spice with vast traditional and historical uses. Molecules 17(9): 10159-10177.

11. Haloci E, Manfredini S, Toska V, Vertuani S, Ziosi P, et al. (2012) Antibacterial and antifungal activity assesment of nigella sativa essential oils. International Scholarly and Scientific Research \& Innovation 6(6): 1087-1089.

12. Ullah R, Rehman A, Zafeer MF, Rehman L, Khan YA, et al. (2017) Anthelmintic potential of thymoquinone and curcumin on fasciola gigantic. PLoS ONE 12(2): 1-19.

13. Shaaban HA, Sadek Z, Edris AE, Saad-Hussein A (2015) Analysis and antibacterial activity of nigella sativa essential oil formulated in microemulsion system. J Oleo Sci 64(2): 223-232.

14. Khan MAU, Ashfaq MK, Zuberi HS, Mahamood MS, Gilani AH (2003) The in vivo antifungal activity of the aqueous extract from Nigella sativa seeds. Phytother Res 186: 183-186.

15. Agyare C (2000) Medicinal plants and natural products with Demonstrate wound healing properties.

16. Akram K (2016) Chemical composition of Nigella sativa. BioMed Research International 67-79.

17. Afzal MM (2016) Chemical composition of Nigella sativa Linn : Part 2 Recent advances. Inflammopharmacology 24(2): 67-79.

18. Besra M, Kumar V (2018) In vitro investigation of antimicrobial activities of ethnomedicinal plants against dental caries pathogens. 3 Biotech 8(5): 257.

19. Billore (2014) Database on medicinal plants used in Ayurveda, central council of research in Ayurveda and Siddha, India. $7:$ 38-42.
20. Burits M (2000) Antioxidant activity of nigella sativa essential oil. Phytother Res 14(5): 323-328.

21. Chaieb K, Kouidhi B, Jrah H, Mahdouani K, Bakhrouf A (2011) Antibacterial activity of thymoquinone, an active principle of Nigella sativa and its potency to prevent bacterial biofilm formation. BMC Complementary and Alternative Medicine 11.

22. Darand AM, Darabi Z, Yari Z, Alavian S (2019) Nigella sativa and inflammatory biomarkers in patients with non-alcoholic fatty liver disease: Results from a randomized, double-blind, placebo-controlled, clinical trial. Complementary Therapies in Medicine 44: 204-209.

23. Fanoudi S, Alavi MS, Hosseini M, Sadeghnia H (2019) Nigella sativa and thymoquinone attenuate oxidative stress and cognitive impairment following cerebral hypoperfusion in rats. Metab Brain Dis 34: 10011010.

24. Hariharan P, Paul-Satyaseela M, Gnanamani A (2016) In vitro profiling of antimethicillin-resistant Staphylococcus aureus activity of thymoquinone against selected type and clinical strains. Lett Appl Microbiol 62(3): 283-289.

25. Kazemi M (2014) Phytochemical composition, antioxidant, antiinflammatory and antimicrobial activity of nigella sativa l. essential oil. Journal of Essential Oil-Bearing Plants 17(5): 1002-1011.

26. Kokoska L, Havlik J, Valterova I, Sovova H, Sajfrtova M, et al. (2016) Comparison of chemical composition and antibacterial activity of nigella sativa seed essential oils obtained by different extraction methods. Journal of Food Protection 71(12): 2475-2480.

27. Landa P, Marsik P, Havlik J, Kloucek P, Vanek T, et al. (2009) Evaluation of antimicrobial and anti-inflammatory activities of seed extracts from six nigella species. J Med Food 12(2): 408-415.

28. Mahmoudvand H, Sepahvand A, Jahanbakhsh S, Ezatpour B, Ayatollahi Mousavi SA (2014) Evaluation of antifungal activities of the essential oil and various extracts of Nigella sativa and its main component, thymoquinone against pathogenic dermatophyte strains. Journal de Mycologie Medicale, 24(4): e155-e161.

29. Mouwakeh A, Telbisz Á, Spengler G, Mohácsi-Farkas C, Kiskó G (2018) Antibacterial and resistance modifying activities of nigella sativa essential oil and its active compounds against listeria monocytogenes. In Vivo 32(4): 737-743.

30. Sarwar A, Latif Z (2014) GC - MS characterisation and antibacterial activity evaluation of Nigella sativa oil against diverse strains of Salmonella. Natural Product research 29(5): 37-41.

31. Vlachojannis C, Chrubasik-Hausmann S, Hellwig E, Vach K, Al-Ahmad A (2018) Activity of preparations from Spilanthes oleracea, propolis, Nigella sativa and black garlic on different microorganisms involved in oral diseases and on total human salivary bacteria: A pilot study. Phytother Res 32(10): 1992-2001. 